ORIGINAL ARTICLE

\title{
Prevalence of victims of violence admitted to an emergency department
}

\author{
M-C Hofner, N V Python, E Martin, J-P Gervasoni, B Graz, B Yersin
}

Emerg Med J 2005;22:481-485. doi: 10.1136/emj.2003.013979

See end of article for authors' affiliations .....................

Correspondence to: Dr M-C Hofner, Prevention Unit, IUMSP, Bugnon 21, $\mathrm{CH}-1005$ Lausanne, Switzerland; marie-claude. hofner@hospvd.ch

Accepted for publication 11 July 2004

\begin{abstract}
Objective: To collect data on the consultation frequency and demographic profile of victims of violence attending an emergency department (ED) in Switzerland.

Methods: We undertook screening of all admitted adult patients (>16 years) in the ED of the CHUV, Lausanne, Switzerland, over a 1 month period, using a modified version of the Partner Violence Screen questionnaire. Exclusionary criteria were: life threatening injury (National Advisory Committee on Aeronautics score $\geqslant 4$ ), or inability to understand or speak French, to give oral informed consent, or to be questioned without a family member or accompanying person being present. Data were collected on history of physical and/or psychological violence during the previous 12 months, the type of violence experienced by the patient, and if violence was the reason for the current consultation. Sociodemographic data were obtained from the registration documents.

Results: The final sample consisted of 1602 patients (participation rate of $77.2 \%$ ), with a refusal rate of $1.1 \%$. Violence during the past 12 months was reported by $11.4 \%$ of patients. Of the total sample, $25 \%$ stated that violence was the reason for the current consultation; of these, $95 \%$ of patients were confirmed as victims of violence by the ED physicians. Patients reporting violence were more likely to be young and separated from their partner. Men were more likely to be victims of public violence and women more commonly victims of domestic violence.

Conclusions: Based on this monthly prevalence rate, we estimate that over 3000 adults affected by violence consult our ED per annum. This underlines the importance of the problem and the need to address it. Health services organisations should establish measures to improve quality of care for victims. Guidelines and educational programmes for nurses and physicians should be developed in order to enhance providers' skills and basic knowledge of all types of violence, how to recognise and interact appropriately with victims, and where to refer these patients for follow up care in their local networks.
\end{abstract}

in nterpersonal violence has been the subject of much recent interest as a public health issue in developed countries. ${ }^{1}$ According to the Swiss 2000 Health Inquiry, 1 in 10 people in Switzerland admits having been a victim of violence during the past year, and about 40000 women could be considered as having a serious health problem related to violence. ${ }^{23} \mathrm{~A}$ study conducted in Switzerland in 1994 showed that 1 in 5 women had experienced domestic physical or sexual violence at least once in their lifetime. ${ }^{45}$ These numbers are very similar to those from many other countries. ${ }^{6}$

Being a victim of interpersonal violence may result in physical injury or death. In addition, living in a violent setting can affect health, including an increase in chronic somatic diseases, alcohol and substance misuse, depression, suicide, eating disorders, and non-compliance with medical treatment, all of which lead to increased use of medical services and resources. ${ }^{78}$ Violent settings also pose a risk for children and elderly people. ${ }^{10}$

Of health services, emergency departments (ED) are most frequently called upon to treat patients that are victims of violence. Patients may consult an ED specifically because of violence related injuries (regardless of their public or domestic cause), to ask for treatment, and/or to make an injury report. About $2.5 \%$ of all patients consulting an ED in the UK are victims of assaults or violent offence occurring in the community, and this statistic is 3-10 times higher than that found in police records. ${ }^{11}$ In addition, people living in a violent situation may consult an ED, regardless of the motive for consultation, more frequently than usual. Several studies have shown the general prevalence of victims of domestic violence among patients consulting an ED to be between 12 and $26 \%,{ }^{8}{ }^{12}$ with fewer than 1 in 25 being spontaneously identified by health workers. ${ }^{13}{ }^{23}$ One woman in four seeking care in an ED, for any reason, is a victim of domestic violence. ${ }^{9}$ Professionals working in ED are often poorly equipped to manage such situations, and services do not usually address this health problem.

More knowledge about frequency of consultation, characteristics of victims, and type of violence among people attending an ED is needed in order to develop screening policies and identification strategies for patients at risk, to provide quality care, and to develop relevant educational programmes. A study was therefore conducted in 2002 in the ED of a Swiss university teaching hospital in order to collect data about the ED point prevalence and the profile of people who are victims of violence. More precisely, the study was aimed at $(a)$ determining the proportion and characteristics of adults consulting the medical and surgical wards of the ED who had a positive result on a brief violence screening questionnaire; and $(b)$ comparing the number of these patients with the number of patients requesting an injury report. This paper summarises the main findings of this study.

\section{METHODS}

Study design and population

The ED of the university hospital where the study took place registered 41 467 patients in 2001 for a population area of

Abbreviations: ED, emergency department; NACA, National Advisory Committee on Aeronautics; PDNV, patients declaring having experienced no violence during the previous 12 months; PDV, patients declaring having experienced violence during the previous 12 months 


\begin{tabular}{|l|l|}
\hline QUESTIONNAIRE VIOLENCE «PVS» & \\
Résultats $p$ & Etiquette collée ici \\
PVS - $\quad$ PVS + & \\
Suivi médical souhaité & \\
OUI NON & \\
\hline
\end{tabular}

1. Avez-vous été frappé par quelqu'un, avez-vous reçu des coups de poing ou de pieds ou d'autres coups durant l'année écoulée, y compris durant les dernières $24 \mathrm{~h}$ ? oui $\square$ non $\square$

2. Avez-vous été menacé ou contraint par quelqu'un durant l'année écoulée, y compris durant les dernières $24 \mathrm{~h}$ ? oui $\square$ non $\square$

p Si 2 réponses négatives (4) arrêt du questionnaire $=$ PVS -

p Si 1 ou 2 réponses positives poursuivre le questionnaire $=P V S+$

3. Si oui par qui ? (plusieurs réponses possibles) tiers inconnu

tiers connus et/ou inconnus sur la voie publique agression en bande

amis/connaissances en privé

conjoint/conjointe

autre, précisez.

autre personne vivant dans le ménage

enfant/membre de la famille

professionnel dans l'exercice de ses fonctions

4. Vous sentez-vous en sécurité avec votre partenaire ou avec votre entourage ? oui $\square$ non $\square$

5. Y a-t-il un partenaire ou une personne de votre entourage, actuel ou passé, qui provoque en vous un sentiment d'insécurité en ce moment ? ovi $\square$ non $\square$

6. Ces circonstances sont-elles à l'origine de votre demande actuelle de consultation ? ovi $\square$ non $\square$

7. Souhaitez-vous que le médecin aborde cette situation avec vous ? oui $\square$ non $\square$

8. Le questionnaire n'a pas pu être rempli parce que : (plusieurs réponses possible)

$\square$ refus de la personne

score NACA > 4

problème de langue et/ou de compréhension

oubli du team CIU

discordance évidente entre la réponse du patient et l'observation du soignant (= faux négatif)

incapacité du team du CIU, précisez : (par exemple un accompagnant s'oppose)

Figure 1 Modified PVS in French.

approximately 250000 inhabitants. ${ }^{14}$ Monitoring was conducted between 1 and 31 March 2002. During that period, all consecutively admitted adult patients (>16 years old), regardless of the cause of admission, were eligible for the study. Criteria for exclusion were: patients with life threatening injuries (National Advisory Committee on Aeronautics score $\geqslant 4$ ), or inability to understand or speak French, to give oral informed consent, or to be questioned without the presence of a family member or accompanying person. After providing oral informed consent, the patient was asked the screening questions by the nurse in charge. Patients received written information about the study and were also provided local sources ofmedical, social, and legal support in case of violence.

\section{Study protocol}

This study was submitted to and approved by the hospital's academic research ethics committee (positive pre-study review by the institutional review board).

The screening questionnaire was the Partner Violence Screen (PVS), developed and validated in Denver. ${ }^{15}{ }^{16}$ For the purpose of this study, the PVS was translated into French, and minor modifications were made, namely, two questions about feelings of insecurity were added to the initial questionnaire on the recommendation of the ED researchers in Denver. In addition, two other questions were added, one concerning the relationship between violence and actual consultation, and another concerning willingness to discuss the problem with a medical doctor (see fig 1 for the modified, translated questionnair). Nurses discreetly administered the questionnaire while they settled the patient into the cubicle and performed the routine examination. If the answer to the first two questions was "No", the screening test was considered negative and was stopped. Conversely, if the answer to one of the first two questions was "Yes", the test was considered positive, and the other questions were completed. When it was not possible to interview a patient, the nurse wrote the main reason for this on the questionnaire. Completed questionnaires were then put into a special box in the ED. Time to complete the questionnaire was about 20 seconds. Patients declaring having experienced violence during the previous 12 months (PDV) were those with a positive PVS whereas patients declaring having experienced no violence during the previous 12 months (PDNV) were those with a negative PVS.

\section{Data analysis}

Based on an expected prevalence of about $10 \%$, the duration of the study needed to obtain the required sample size was 31 days. This period was also estimated to be optimum to ensure sustained attention from the care providers-that is, administering the questionnaire as part of their usual activities. In addition to the information gathered by the questionnaire, sociodemographic data, which are recorded systematically for any admitted patient, were also collected. Statistical analyses were conducted with SPSS for Windows (version 11.0). ${ }^{17} \chi^{2}$ tests were performed where applicable and $\mathrm{p}<0.05$ considered statistically significant.

\section{RESULTS}

In total, 2454 adult patients were treated in the medical and surgical wards of the ED during the study period. Completed questionnaires were obtained from 1894 patients, resulting in a participation rate of $77.2 \%$. Non-participants differed on 
Table 1 Main sociodemographic characteristics of PVS positive and negative participants

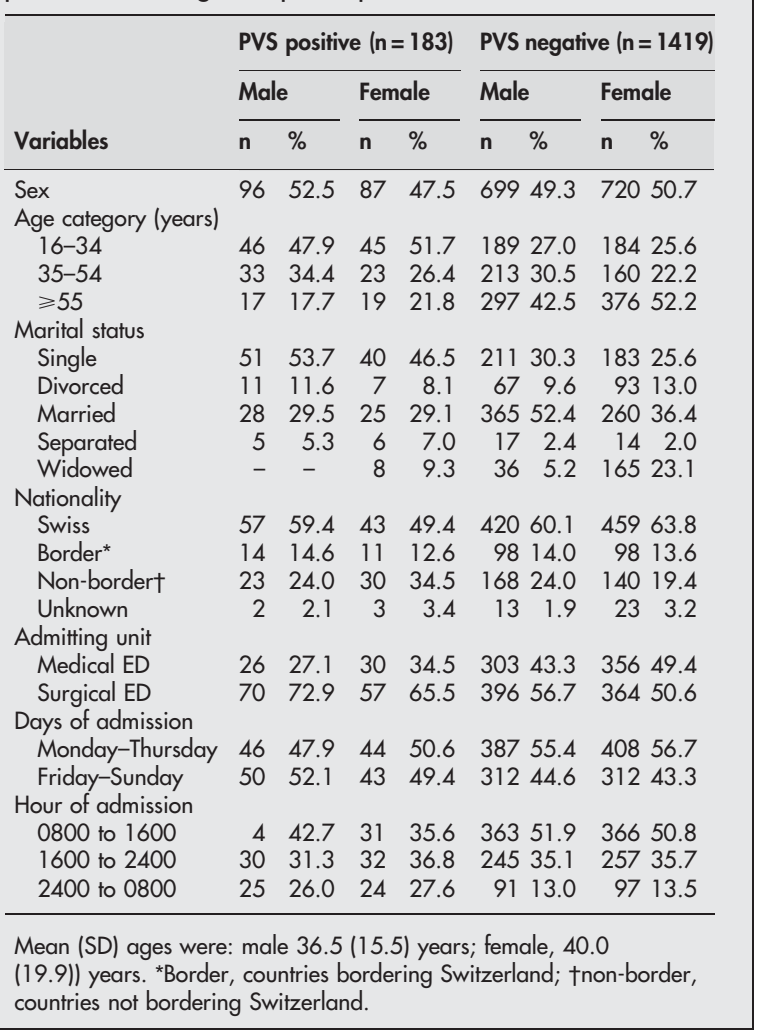

almost all variables (excluding civil status and nationality). They were more likely to have been young, male, treated in the surgery ward, and admitted Wednesday to Sunday night between 1600 and 2400 hours. Of the 1894 patients who completed the questionnaire, 270 were ineligible and 22 refused to participate in the study ( 11 women and 11 men). The refusal rate was thus $1.1 \%$ and the final sample consisted of 1602 patients.

The main characteristics of the patients based upon the results of the PVS screen are presented in table 1 . The general prevalence of PDV was $11.4 \%(n=183)$. Of these, $42 \%$ of cases reported only psychological violence, $18 \%$ only physical violence, and $40 \%$ both types of violence (data not shown). In PDV group, the proportion of men was slightly higher, and they tended to be younger and single. The majority of the women were non-Swiss nationals, more often admitted to the surgical ward (because of trauma), and seen slightly more often during nights (from 2400 to 0800 hours) and the weekend.

The prevalence of PDV according to the sociodemographic characteristics of the patients is shown in table 2 . There was a significantly higher prevalence of PDV among people aged 16-34 years (19.6\%), among those admitted to the surgical $(14.3 \%)$ rather than to the medical ward $(7.8 \%)$, and among those consulting between 2400 and 0800 hours (20.7\%). The highest prevalence of PDV was found among those who were separated from their partners $(26.2 \%)$. The lowest prevalence $(3 \%)$ was found among people aged $\geqslant 64$ years. No significant differences in sex or nationality were found.

The main type of violence occurred in public places (table 3), with men more frequently involved than women. Conversely, domestic violence, the second most reported type of violence, more commonly involved women as victims. Violence occurring in the workplace was more prevalent among men.

\begin{tabular}{|c|c|c|}
\hline Variables & $\begin{array}{l}\text { Prevalence } \\
\text { of positive } \\
\text { PVS }(\%)\end{array}$ & $95 \% \mathrm{Cl}$ \\
\hline \multicolumn{3}{|l|}{ Sex } \\
\hline Male & 12.1 & 9.8 to 14.4 \\
\hline Female & 10.8 & 8.7 to 12.9 \\
\hline \multicolumn{3}{|l|}{ Age category (years) } \\
\hline $16-34$ & 19.6 & 16.0 to 23.2 \\
\hline $35-54$ & 13.1 & 9.9 to 16.3 \\
\hline$\geqslant 55$ & 5.1 & 3.5 to 6.7 \\
\hline \multicolumn{3}{|l|}{ Marital status } \\
\hline Single & 18.8 & 15.3 to 22.3 \\
\hline Divorced & 10.1 & 5.7 to 14.5 \\
\hline Married & 7.8 & 5.8 to 9.8 \\
\hline Separated & 26.2 & 11.1 to 41.3 \\
\hline Widowed & 3.8 & 1.2 to 6.4 \\
\hline \multicolumn{3}{|l|}{ Nationality } \\
\hline Swiss & 10.2 & 8.3 to 12.1 \\
\hline Border* & 11.3 & 7.1 to 15.5 \\
\hline Non-bordert & 14.7 & 11.0 to 18.4 \\
\hline Unknown & 12.2 & -3.1 to 27.5 \\
\hline \multicolumn{3}{|l|}{ Unit of admission } \\
\hline Medical ED & 7.8 & 5.8 to 9.8 \\
\hline Surgical ED & 14.3 & 12.0 to 16.6 \\
\hline \multicolumn{3}{|l|}{ Days of admission } \\
\hline Monday-Thursday & 10.2 & 8.2 to 12.2 \\
\hline Friday-Sunday & 13.0 & 10.5 to 15.5 \\
\hline \multicolumn{3}{|l|}{ Hours of admission } \\
\hline 0800 to 1600 & 9.0 & 7.0 to 11.0 \\
\hline 1600 to 2400 & 11.0 & 8.5 to 13.7 \\
\hline 2400 to 0800 & 20.7 & 15.5 to 25.9 \\
\hline
\end{tabular}

More than half of the PDV group were aged 16-34 years. Only 16 patients $(8.7 \%)>65$ years of age reported violence on the PVS, and no-one aged over 94 years screened positively.

Of the $183 \mathrm{PDV}, 46$ (25\%) declared that violence was the reason for the current consultation (giving an overall incidence rate of $2.8 \%$ ), and of these, 25 patients received an injury report, 19 had violence mentioned in their medical records, and 2 had neither. Overall, violence was identified in the medical record or by the establishment of an injury report in $95 \%$ of PDV declaring violence to be their reason for the current consultation.

Table 3 Type of reported violence according to age category and gender

\begin{tabular}{|c|c|c|c|c|c|c|}
\hline \multirow{2}{*}{$\begin{array}{l}\text { Age category and } \\
\text { type of violence }\end{array}$} & \multicolumn{2}{|c|}{ Number } & \multicolumn{2}{|c|}{ Proportion (\%) } & \multicolumn{2}{|c|}{ PVS positive } \\
\hline & Men & Women & Men & Women & $\mathbf{n}$ & $\%$ \\
\hline \multicolumn{7}{|l|}{$16-34$ years } \\
\hline Public & 37 & 23 & 61.7 & 38.3 & 60 & 63.2 \\
\hline Domestic & 4 & 19 & 17.4 & 82.6 & 23 & 24.2 \\
\hline Workplace related & 6 & 3 & 66.7 & 33.3 & 9 & 9.5 \\
\hline Other* & 2 & 1 & 66.7 & 33.3 & 3 & 3.2 \\
\hline Total & 49 & 46 & 51.6 & 48.4 & 95 & 100.0 \\
\hline \multicolumn{7}{|l|}{$35-54$ years } \\
\hline Public & 19 & 9 & 67.9 & 32.1 & 28 & 52.8 \\
\hline Domestic & 6 & 9 & 40.0 & 60.0 & 15 & 28.3 \\
\hline Workplace related & 5 & 3 & 62.5 & 37.5 & 8 & 15.1 \\
\hline Other* & 1 & 1 & 50.0 & 50.0 & 2 & 3.8 \\
\hline Total & 31 & 22 & 58.5 & 41.5 & 53 & 100.0 \\
\hline \multicolumn{7}{|l|}{$>55$ years } \\
\hline Public & 11 & 11 & 50.0 & 50.0 & 22 & 62.9 \\
\hline Domestic & 2 & 6 & 25.0 & 75.0 & 8 & 22.9 \\
\hline Workplace related & 2 & 0 & 100.0 & 0.0 & 2 & 5.7 \\
\hline Other* & 1 & 2 & 33.3 & 66.7 & 3 & 8.6 \\
\hline Total & 16 & 19 & 45.7 & 54.3 & 35 & 100.0 \\
\hline
\end{tabular}




\section{DISCUSSION}

Approximately 1 in 10 adult patients attending the surgical or medical units of the ED of this university hospital declared having experienced physical and/or psychological violence during the previous 12 months, resulting in an overall prevalence of reported violence of $11.4 \%$. Of these patients, $25 \%$ declared violence as their reason for the current consultation, which was confirmed by the emergency physicians, but only half completed an injury report. Even if immediate physical violence is usually identified by emergency physicians, it is evident that injury report rates reflect neither the true prevalence of victims of violence among patients nor the incidence of immediate physical violence.

A comparison with prevalence rates obtained in other studies is difficult, owing to factors such as variations in methodology, categories of patients studied, definition and type of violence, and setting. ${ }^{18}$ For example, in our study, the PVS screen showed that 34 of 807 women $(4.2 \%)$ and 12 of 195 men (1.5\%) declared having experienced domestic violence, whereas in the Denver study, the overall prevalence for female victims of domestic violence admitted to a general ED ward was $29.5 \% .{ }^{15}$ Our prevalence rate does not include sexual violence because women seen in the emergency gynaecology/obstetric ward were not included in our study population. Similar issues arose when we analysed the prevalence rate of PDV among elderly patients. Despite numerous reports, including from Switzerland, that violence and related behaviours are frequently encountered among the elderly, it is striking to note that in this sample, the PVS was rarely positive among patients aged $\geqslant 65$ years and never in those $>95$ years. This observation may indicate low sensitivity of the PVS in this specific population.

In terms of external validity, the national health survey in Switzerland shows an overall prevalence of $9 \%$ of reported violence during the previous 12 months among people aged $15-75$ years and over ( $10 \%$ of men and $8 \%$ of women). This includes three types of violence: psychological, physical, and offence against property. ${ }^{2}$ In the present study, the prevalence of physical and/or psychological violence only was $12.1 \%$ for men and $10.8 \%$ for women, which is a higher rate than in the general population.

The majority of patients admitted to the ED agreed to be questioned about violence, with a refusal rate of only $1.1 \%$. This is in accordance with previous studies showing patients' readiness to be asked about violence. ${ }^{19}$ Interestingly, there was no difference in refusal rates between men and women. Despite the barriers to asking patients about violence that are cited in the literature and that were mentioned by nurses and physicians during the pre-test period, the number of questionnaires completed was relatively high $(22.8 \%$ missing). This confirms the results of several studies, which showed differences between the representations and beliefs of health professionals and the willingness of patients to be asked about violent behaviour. ${ }^{20}{ }^{21}$ When nurses have the sole responsibility of distributing and collecting a self administered questionnaire, response rates in ED screening studies are about $70-80 \%{ }^{13}$ In our study, a response rate of $77.2 \%$ was achieved despite a demanding study design. Early involvement of ED nurses in the design of the study and regular presence in the ED of the researchers may explain our high response rate.

There are some limitations to this study. A full $22.8 \%$ of patients admitted to the medical or surgical wards during the survey period were not included in our sample. They differed from participants on all main sociodemographic factors. Nonparticipation by these individuals is explained by increased activity and reduced staffing in the surgery ward at night and during weekends. Patient overload may have made it difficult for nurses to enrol patients systematically in an ongoing manner during those times. The sociodemographic characteristics of non-questioned patients (young men, treated in surgery ward, admitted from Wednesday to Sunday night) and the increased rate of public violence in this population suggests that we may have underestimated our overall public violence rate.

The original Denver study using the PVS screening questionnaire included only women and focused exclusively on domestic violence. In our study, the PVS questionnaire was used to screen both women and men for all types of interpersonal violence. To accomplish this, we made some slight modifications to the original questionnaire. We also translated it into French to adapt it to the study population. These modifications may have decreased the questionnaire validity, possibly diminishing the strength of our observations.

This short, well accepted, and easily administered PVS questionnaire established a high prevalence of reported violence by patients admitted to an emergency department of a general hospital (11.4\%). Despite its limitations, our study clearly demonstrates that a large number of victims seeking treatment for recent violence do not receive an injury report even though immediate physical violence is generally identified by emergency staff. ${ }^{22}$ This discrepancy indicates the usefulness of this type of questionnaire.

\section{ACKNOWLEDGEMENTS}

We are indebted to the members of the nursing staff of the emergency department of the CHUV for their continuous interest and daily support for this study and more importantly, for the ongoing nursing skills and humane treatment provided to the victims of violence.

\section{Authors' affiliations}

M-C Hofner, N V Python, E Martin, J-P Gervasoni, Prevention Unit, University Institute of Social and Preventive Medicine (IUMSP), Lausanne, Switzerland

B Graz, B Yersin, Department of Emergency Medicine, CHUV, Lausanne, Switzerland

Competing interests: none declared

\section{REFERENCES}

1 Concha-Eastman A. Violence: a challenge for public health and for all. $J$ Epidemiol Community Health 2001;55:597-9.

2 Calmonte R, Weiss W, Koller C. Santé et comportements vis-à-vis de la santé en Suisse 1997. Neuchâtel: Office Fédéral de la Statistique (OFS), 2000.

3 Fonds national suisse de la récherce scientifique. Rapport sur la santé des femmes en Suisse. Des données pour agir. Berne: Fonds National de la Recherche Scientifique, 1996.

4 Gillioz L, De Puy J, Ducret V. Domination et violence envers la femme dans le couple. Lausanne: Editions Payot, 1997.

5 Godenzi AeYC. Erster Bericht zu den oekonomischen Kosten der Gewalt gegen Fraven. Fribourg: Université de Fribourg 1, 2001.

6 Organisation Mondiale de la Santé. Rapport mondial sur la violence et la santé: résumé. Geneva: WHO, 2002.

7 Brokaw J, Fullerton-Gleason L, Olson L, et al. Health status and intimate partner violence: a cross-sectional study. Ann Emerg Med 2002;39:31-8.

8 Jewkes R. Preventing domestic violence. BMJ 2002;324:253-4.

9 Eisenstat SA, Bancroff L. Domestic violence. N Engl J Med 1999;341:886-92.

10 Fulmer T, Paveza G, Abraham I, et al. Elder neglect assessment in the emergency department. J Emerg Nurs 2000;26:436-43.

11 Sivarajasingam V, Shepherd JP. Trends in community violence in England and Wales 1995-1998: an accident and emergency department perspective. Emerg Med J 2001;18:105-9.

12 Roberts GL, Lawrence JM, O'Toole Bl, et al. Domestic violence in the Emergency Department: 2. Detection by doctors and nurses. Gen Hosp Psychiatry 1997; 19:12-15.

13 Ellis JM. Barriers to effective screening for domestic violence by registered nurses in the emergency department. Crit Care Nurs $Q$ 1999;22:27-41.

14 Hugli O, Yersin B. Engorgement chronique des urgences du CHUV. Une situation qui menace les missions d'un service d'urgences. Courrier Du Médecin Vaudois 2002;4:5-7. 
15 Feldhaus KM, Koziol-McLain J, Amsbury HL, et al. Accuracy of 3 brief screening questions for detecting partner violence in the emergency department. JAMA 1997;277:1357-61.

16 Castel J. Dépister la violence conjugale oui! mais avec quelles questions? L'actualité médicale 1997. www.fmed.ulaval.ca/mfa-cetp/articles/1997/ 9709 03.htm.

17 SPSS. SPSS base 8.0 userguide. Chicago, IL: SPSS Inc, 1998

18 Shepherd J. Violence in healthcare. Understanding, preventing and surviving violence. A practical guide for health professionals. Oxford University Press, 2001.

19 Ramsay J, Richardson J, Carter YH, et al. Should health professionals screen women for domestic violence? Systematic review. BMJ 2002;325:314.
20 Howe A, Crilly M, Fairhurst R. Acceptability of asking patients about violence in accident and emergency. Emerg Med J 2002; 19:138-40.

21 Waalen J, Goodwin MM, Spitz AM, et al. Screening for intimate partner violence by health care providers. Barriers and interventions. Am J Prev Med 2000;19:230-7.

22 Wathen CN, MacMillan HL. Interventions for violence against women: scientific review. JAMA 2003;289:589-600.

23 Tjaden $\mathbf{P}$, Thoennes N. Prevalence, incidence, and consequences of violence against women: findings from the national violence against women survey. Research in brief. US: National Institute of Justice Centers for Disease Control and Prevention, 1998.

\section{Clinical Evidence - Call for contributors}

Clinical Evidence is a regularly updated evidence-based journal available worldwide both as a paper version and on the internet. Clinical Evidence needs to recruit a number of new contributors. Contributors are healthcare professionals or epidemiologists with experience in evidence-based medicine and the ability to write in a concise and structured way.

Areas for which we are currently seeking authors:

- Child health: nocturnal enuresis

- Eye disorders: bacterial conjunctivitis

- Male health: prostate cancer (metastatic)

- Women's health: pre-menstrual syndrome; pyelonephritis in non-pregnant women

However, we are always looking for others, so do not let this list discourage you.

\section{Being a contributor involves:}

- Selecting from a validated, screened search (performed by in-house Information Specialists) epidemiologically sound studies for inclusion.

- Documenting your decisions about which studies to include on an inclusion and exclusion form, which we keep on file.

- Writing the text to a highly structured template (about 1500-3000 words), using evidence from the final studies chosen, within 8-10 weeks of receiving the literature search.

- Working with Clinical Evidence editors to ensure that the final text meets epidemiological and style standards.

- Updating the text every six months using any new, sound evidence that becomes available. The Clinical Evidence in-house team will conduct the searches for contributors; your task is simply to filter out high quality studies and incorporate them in the existing text.

- To expand the topic to include a new question about once every 12-18 months.

If you would like to become a contributor for Clinical Evidence or require more information about what this involves please send your contact details and a copy of your CV, clearly stating the clinical area you are interested in, to Klara Brunnhuber (kbrunnhuber@ bmigroup.com).

\section{Call for peer reviewers}

Clinical Evidence also needs to recruit a number of new peer reviewers specifically with an interest in the clinical areas stated above, and also others related to general practice. Peer reviewers are healthcare professionals or epidemiologists with experience in evidence-based medicine. As a peer reviewer you would be asked for your views on the clinical relevance, validity, and accessibility of specific topics within the journal, and their usefulness to the intended audience (international generalists and healthcare professionals, possibly with limited statistical knowledge). Topics are usually 1500-3000 words in length and we would ask you to review between 2-5 topics per year. The peer review process takes place throughout the year, and our turnaround time for each review is ideally 10-14 days.

If you are interested in becoming a peer reviewer for Clinical Evidence, please complete the peer review questionnaire at www.clinicalevidence.com or contact Klara Brunnhuber (kbrunnhuber@bmigroup.com). 